\title{
Pemberdayaan Masyarakat Dalam Pelestarian Dan Pemanfaatan Sumberdaya Budaya (Studi Kasus di Situs Candi Morangan)
}

\section{Masyhudi}

Keywords: cultural resource management, participation, community, utilization, conservation, heritage

\section{How to Cite:}

Masyhudi, nfn. (2004). Pemberdayaan Masyarakat Dalam Pelestarian Dan Pemanfaatan Sumberdaya Budaya (Studi Kasus di Situs Candi Morangan). Berkala Arkeologi, 24(1), 101-111. https://doi.org/10.30883/jba.v24i1.898

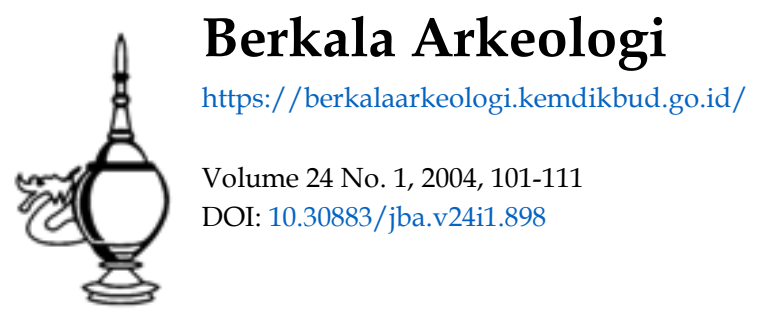

\section{cc) (7) (9)}

This work is licensed under a Creative Commons Attribution-NonCommercial-ShareAlike 4.0 International License. 


\section{PEMBERDAYAAN MASYARAKAT \\ DALAM PELESTARIAN DAN PEMANFAATAN \\ SUMBERDAYA BUDAYA \\ (Studi Kasus di Situs Candi Morangan)}

Masyhudi

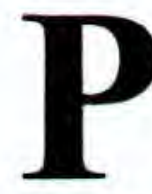

endahuluan

Candi adalah bangunan suci tempat pemujaan dewa. Hal ini telah ditegaskan oleh Soekmono dalam disertasinya yang berjudul Candi Fungsi dan Pengertiannya. Candi melambangkan Mahameru, yaitu gunung yang menjadi pusat alam semesta. Bangunan candi yang biasanya terdiri atas tiga bagian, yaitu kaki, tubuh, dan atap melambangkan tiga dunia, yaitu bhurloka, bherwarloka, dan swarloka (Stutterheim, 1937: 245; Boechari, 1978: 13).

Sebagai bangunan suci keagamaan tentunya diperlukan syarat-syarat khusus dalam pendiriannya. Disebutkan dalam kitab Mânasâra-Çilpaçastra -- kitab yang berisi aturan-aturan pembangunan kuil di India -- bahwa sebelum suatu bangunan kuil didirikan maka arsitek pendeta (sthapaka) dan arsitek perencana (sthapati) harus lebih dahulu menilai kondisi dan kemampuan lahan yang akan dijadikan tempat berdirinya bangunan suci tersebut (Acharya, 1993: 13-21; Kramrisch, 1946: 3-17; Mundardjito, 1993: 13). Kitab tersebut juga menerangkan bahwa lahan tempat berdirinya suatu bangunan kuil dinilai sangat tinggi, bahkan lebih penting dari bangunan suci itu sendiri (Mundardjito, 1993: 239).

Candi Morangan yang terletak di tengah-tengah permukiman penduduk Dusun Morangan, Desa Sindumartani, Kecamatan Ngemplak, Kabupaten Sleman, Propinsi Daerah Istimewa Yogyakarta, pada saat ditemukan, sebagian besar dari sisa-sisa batu candi berada di permukaan, namun pada kondisi sekarang batu-batu candi tersebut telah diangkat untuk direkonstruksi Pada bagian dasar (kaki bangunan candi) berukuran $750 \times 750$ sentimeter dengan ketinggian belum diketahui secara pasti karena bangunan candi tersebut belum dipugar sehingga pada beberapa bagian yang lain termasuk arsitektur candi secara secara utuh belum diketahui.

Dilihat dari besaran bangunan candi dan sedikitnya atribut yang terdapat pada bangunan candi, candi tersebut merupakan candi yang berlatar belakang agama Hindu dan merupakan bangunan candi yang berstatus wanua (candi tingkat Desa), sedangkan untuk candi pada tingkat kota atau yang dikenal dengan istilah watak akan terdapat ciri-ciri bahwa suatu bangunan candi berukuran lebih besar dan lebih kaya dengan atribut (ornamen dan arca) dibanding dengan candi pada tingkat desa (wanua). 
Secara historis setelah bangunan Candi Morangan ini lama terpendam dan kemudian muncul kembali, secara temporal bangunan candi tersebut telah mengalami masa guna dan masa vacum. Masa guna dimaksud adalah bahwa Candi Morangan memiliki peranan yang cukup penting dalam sejarah pemerintahan masa Hindu-Budha di Jawa. Sedangkan masa vacum yang dimaksud adalah karena adanya perpindahan pusat pemerintahan dari Jawa Tengah ke Jawa Timur, atau karena tertimbunnya bangunan candi oleh lahar dingin oleh lahar dingin sebagai akibat dari aktivitas gunung Merapi yang terletah beberapa kilometer di sebelah utara bangunan candi tersebut.

Pada masa Hindu kawasan ini merupakan salah satu pusat pemerintahan Kerajaan Mataram kuna. Poros Kedu-Prambanan diasumsikan sebagai kawasan pusat-pusat pemerintahan Kerajaan Mataram kuna. Dengan demikian Candi Morangan merupakan salah satu candi yang cukup penting pada masa itu karena berada di kawasan pusat pemerintahan Kerajaan Mataram Kuna. Karena dekatnya dengan Candi Prambanan, candi ini kemungkinan merupakan salah satu underbouw Candi Prambanan.

Sejak ditemukannya bangunan candi Morangan tersebut, muncul berbagai pihak yang merasa berkepentingan terhadap situs tersebut, sehingga dengan kepentingankepentingan tersebut sangat besar kemungkinannya muncul berbagai konfliks yang kemungkinan dapat berakibat terancamnya kelestarian situs tersebut. Oleh karena itu langkah yang harus dilakukan adalah penyelamatan dalam rangka upaya pelestarian dan pemanfaatan terhadap situs candi Morangan sebagai bangunan yang memiliki nilai penting bagi sejarah dan kebudayaan. Namun yang menjadi masalah atau persoalan adalah bagaimana upaya pengelolaan terhadap sumberdaya tersebut seharusnya dilakukan ? Oleh karena itulah makalah ini akan memberikan gambaran tentang beberapa pendekatan yang ideal untuk dilakukan dalam upaya penyelamatan terhadap situs candi Morangan yaitu meliputi konservasi, pengembangan sumberdaya manusia dan pemberdayaan masyarakat. Sehingga diharapkan dengan langkahlangkah tersebut, berbagai konfliks kepentingan dapat teratasi.

\section{$\mathbf{P}$}

\section{engelolaan Sunberdaya Budaya}

Pada dasarnya budaya atau kebudayaan merupakan suatu karya dari individu atau kelompok manusia yang sekaligus merupakan sistem nilai yang dihayati oleh sekelompok manusia. Sementara itu hasil kebudayaan itu sendiri dapat dibedakan menjadi dua kelompok, yaitu hasil budaya yang secara fisik dapat dilihat dan disentuh (tangible), misalnya candi, gua, masjid, gereja, rumah adat, benteng, kuil dan lain sebagainya. Sedangkan yang satu lagi adalah hasil budaya yang secara fisik tidak dapat disentuh (intangible), seperti ilmu pengetahuan, teknologi, adat-istiadat, kesenian, hukum, pendidikan, prilaku, gagasan dan lain sebagainya. 
Kebudayaan dengan berbagai pengertian yang ada, pada hakekatnya berkembang sebagai perwujudan dari tanggapan aktif manusia terhadap lingkungannya. Dengan segala kemampuan yang dimiliki, manusia berusaha melihat memahami, dan memilah gejala yang ada untuk kemudian merencanakan tindakan, menentukan sikap untuk suatu perbuatan yang menghasilkan karya. Pada mulanya manusia menanggapi lingkuangan di sekitarnya dengan berbagai pengalaman yang didasari pada suatu sikap trial and error, salah mencoba, salah mencoba dan seterusnya. Oleh karena itu cepat lambatnya perkembangan suatu kebudayaan tergantung daripada sedikit banyaknya umpan balik yang dapat ditangkap oleh akal manusia dalam mengelola lingkungannya.

Suatu tanggapan yang mendatangkan hasil yang positif akan selalu diulang-ulang untuk menghadapi tantangan serupa yang pada akhirnya menguat dan seringkali dikukuhkan oleh komunitas yang bersangkutan. Melalui cara bersikap dan bertingkah laku, seseorang dapat berasumsi apa yang sebaiknya dilakukan atau dihindarkan. Seseorang dapat saja menarik suatu gagasan dari tingkah laku yang berpola sebagai pegangan, disamping itu seseorang juga dapat memperoleh keyakinan dengan memahami sistem sosial yang telah menguat. Nilai-nilai, gagasan, dan keyakinan sebagai abstraksi dari sistem sosial yang berlaku itulah yang kita artikan sebagai kebudayaan yang kemudian menjadi pedoman bagi pola tingkah laku masyarakat pendukungnya. Dengan demikian kebudayaan dapat kita artikan sebagai sistem nilai, gagasan yang mendominasi cara pendukungnya melihat, memahami, memilah-milah gejala yang dilihatnya, merencanakan dan menentukan sikap dan perbuatan selajutnya.

Sementara itu dalam hal pengembangan sumberdaya budaya, seharusnya kita ketahui atau kita pelajari terlebih dahulu tentang nailai-nilai dan makna kultural yang terdapat di dalamnya. Sumberdaya budaya yang bersifat tangible, sebagai karya manusia dari masa lalu yang juga dikenal sebagai warisan budaya tersebut hendaknya dijunjung tinggi, karena di dalamnya terdapat nilai-nilai tinggi yang terlihat melalui nilai-nilai sosial dan individu yang membentuk jalinan tradisi dan adat istiadat yang kernudian menghasilkan produk benda-benda budaya oleh lingkungan masyarakat tertentu dan pada zaman tertentu pula.

Karya-karya budaya yang memiliki kepastian dalam bentuk fisik akan dapat berubah maknanya, bahkan sering menemukan makna baru yang jauh berbeda dengan arti penciptaan semula. Konsep kebudayaan tradisional dan moderen pada dasarnya menunjukkan dinamika perkembangan budaya masyarakat yang sama di dalam menempuh perubahan-perubahan zaman. Oleh karenanya kebudayaan dapat disebut sebagai perwujudan dari kemampuan keseluruhan hidup masyarakat dalam menghadapi tantangan lingkungan secara spasial dan temporal dalam upaya mewujudkan pengalaman kehidupannya. 

elestarian Istilah pelestarian dalam arkeologi dapat di samakan dengan konservasi yang berarti suatu kegiatan yang berhubungan dengan pengelolaan dan perlindungan terhadap peninggalan-peninggalan arkeologi. Pada mulanya istilah konservasi berhubungan dengan cara pemanfaatan terhadap sumberdaya alam, misalnya tanah, air, tanaman, binatang, mineral dan lain sebagainya. Akan tetapi dalam hal ini konservasi dimaksudkan sebagai upaya di dalam memanfaatkan tanah dan sumberdaya alam yang lain secara bijaksana sehingga tanah dan sumberdaya alam tersebut dapat dimanfaatkan lebih lama.

Dari sudut pandang estetis inilah konservasi berkembang menjadi suatu upaya pemeliharaan sumberdaya alam termasuk situs-situs arkeologi dan sejarah. Peninggalan-peninggalan arkeologi beserta situs-situsnya merupakan aset budaya bangsa yang memiliki nilai yang sangat tinggi. Oleh karena itu agar aset budaya bangsa tersebut dapat dimanfaatkan selama mungkin, maka perlu dilakukan konservasi. Dari sini, konservasi diartikan sebagai suatu proses pemeliharaan terhadap situs (lokasi) agar makna kulturalnya (nilai-nilai yang melekat pada obyek yang dikonservasi, yaitu nilai estetis, nilai historis, nilai sosial dan nilai akademis) tetap terpelihara.

Dari pengertian tersebut di atas, jelaslah bahwa konservasi bagi arkeologi bertujuan untuk mengelola dan memelihara, (memelihara peninggalan-peninggalan arkeologi beserta situs-situsnya) dengan berbagai cara seperti tersebut di atas agar dapat dimanfaatkan lebih lama dengan memperhatikan makna kulturalnya.

Oleh karena sumberdaya Arkeologi sebagai bagian dari sumberdaya budaya memiliki sifat yang spesifik maka sumberdaya arkeologipun memerlukan suatu penanganan yang spesifik dan profesional. Artinya pelaku pengelolaan harus melakukan pekerjaannya secara bertanggungjawab. Untuk itu diperlukan adanya suatu perencanaan yang matang, mulai dari metode atau teknis pelaksanaan sampai dengan penyebarluasan informasi, pengorganisasian, pelaksanaan, pengawasan dan evaluasi kerja, sehingga seluruh kegiatan akan dapat berjalan secara efektif dan efisien.

Selain itu, penyebar luasan informasi mengenai hasil yang diperoleh dalam suatu kegiatan harus dilakukan, yaitu menyampaikan informasi kepada publik (masyarakat luas) agar dapat memberi manfaat yang seimbang bagi semua pihak, karena sumberdaya budaya, sebagaimana sumberdaya lainnya adalah warisan untuk seluruh masyarakat, sehingga segala sesuatu yang terjadi padanya harus sepengetahuan masyarakat. Untuk itu, informasi kepada masyarkat luas sangatlah penting, karena jika masyarakat luas mengetahui dan memahami akan manfaat dan nilai penting suatu sumberdaya budaya, maka masyarkat pun akan merasa ikut memiliki sehingga upaya untuk pelestarian terhadap suatu suberdaya budaya akan terpenuhi. 
Pelestarian Benda Cagar Budaya dan Situs merupakan hal yang mutlak dilaksanakan karena pada dasarnya benda cagar budaya dan situs memiliki sifat-sifat langka, mudah rusak, unik, dan tidak dapat diperbarui (non renewable). Upaya pelestarian Situs Candi Moranagan perlu dilakukan dengan melaksanakan pembebasan tanah, pengupasan candi secara keselurulian, pemugaran dan pemintakatan (zoning). Pelestarian Situs Candi Morangan tentunya juga harus memperhatikan lingkungan hidup, dimana penduduk setempat merupakan salah satu komponen yang perlu dilibatkan.

Pemugaran terhadap bangunan candi Morangan dapat dilakukan apabila sisa-sisa bahan bangunan candi yang tersedia memungkinkan, akan tetapi untuk dapat merekonstruksi bangunan candi secara vertikal dan horizontal. Berdasarkan hasil pengamatan yang kami lakukan dapat diketahui bahwa bangunan candi Morangan tinggal menyisakan bagian kaki dan tubuh candi. Bahan bangunan candi yang tersisa tampaknya belum cukup untuk merekonstruksi bagian badan dan atap candi keseluruhan. Bahkan yang tampak sampai sekarang masih banyak terdapat bagianbagiandari bangunan candi yang berserakan. Hal tersebut jika tidak segera di atasi, maka dikhawatirkan kelestariannya senakin terancam.

\section{$\mathbf{P}$} emanfaatan dan Pengembangan

Dalam pemanfaatan sumberdaya budaya haruslah berorientasi pada pelestarian. Hal ini disebabkan oleh jumlah sumberdaya budaya yang terbatas (finite), tak terbaharui (non renewable), tak dapat dipindahkan (non movable), serta mudah rapuh. Oleh karena itu dalam upaya pemanfaatan terhadap kawasan budaya sebagaimana tersebut di atas hendaknya dimanfaatkan dengan hati-hati. Kemudian dalam hal pengembangan terhadap aset budaya harus pula melihat nilai dari berbagai kepentingan, sehingga berbagai konflik kepentingan yang ada dapat ditekan sesejauh mungkin agar tidak ada upaya untuk saling mengalahakan, tetapi saling menguntungkan.

Situs Candi Morangan sebagai salah satu Benda Cagar Budaya merupakan sumberdaya budaya yang memiliki nilai akademik, ideologik dan ekonomik. Dalam UU RI Nomor 5 Tahun 1992 Tentang Benda Cagar Budaya antara lain dinyatakan bahwa benda cagar budaya dapat dimanfaatkan untuk kepentingan agama, sosial, pariwisata, pendidikan, ilmu pengetahuan dan kebudayaan. Dalam hal ini Situs Candi Morangan dapat dimanfaatkan untuk kepentingan penelitian yang berkesinambungan, pendidikan, penggalian jatidiri bangsa dan daerah (local genius), serta dapat dimanfaatkan untuk kepentingan pariwisata.

Pariwisata yang dapat dikembangkan dalam hal ini adalah pariwisata arkeologi (archaeology tourism). Bentuk parivisata ini merupakan kunjungan ke situs-situs 
arkeologi dan bentanglahan yang ditinggalkan oleh kebudayaan masa lalu. Pariwisata arkeologi merupakan bagian dari ekowisata (ecotourism) yaitu perjalanan ke daerahdaerah alamiah yang bertanggungjawab terhadap pelestarian lingkungan dan dapat meningkatkan kesejahteraan penduduk setempat (Baskoro, 2003).

Candi Morangan merupakan salah satu situs arkeologi yang perlu menjadi bagian dalam program pariwisata arkeologi Candi Prambanan dan candi-candi lain di sekitarnya. Untuk mendukung atraksi dan obyek pariwisata arkeologi, perlu ditampilkan potensi-potensi sumberdaya yang terdapat di sekitar candi. Sumberdaya itu meliputi sumberdaya alam dan sumberdaya budaya. Sumberdaya alam meliputi bentang lahan berupa lembah, bukit, sungai, dataran dan pemandangan alam, sedangkan sumberdaya budaya meliputi kesenian tradisional, kerajinan, dan tradisitradisi budaya yang masih asli dan lestari. Dalam kaitannya dengan penyajian obyek dan atraksi budaya, pemberdayaan masyarakat setempat sangat diharapkan seperti pembuatan cinderamata, norma-norma budaya yang patut dijaga, dan juga pengadaan sarana dan prasarana pariwisata yang ramah lingkungan.

Dalam pariwisata arkeologi ini perlu memperhatikan daya dukung situs arkeologi apabila dikunjungi orang. Dalam hal ini perlu dilakukan studi teknik manajemen pengunjung ke situs-situs arkeologi. Selain itu perlu dibuat panduan untuk wisatawan tentang apa yang boleh dan tidak boleh dilakukan sewaktu melakukan perjalanan wisata ke situs-situs arkeologi. Dengan adanya pengaturan-pengaturan tersebut, diharapkan situs-situs arkeologi dapat dijaga kelestariannya.

\section{1} emberdayaan Mayarakat Dalam Pelestarian dan Pemanfaatan

Berkembangnya suatu sumberdaya budaya (situs candi Morangan) yang dalam pengelolaannya dilakukan suatu upaya pelestarian dan pemanfaatannya, telah berdampak adanya konflik-konflik kepentingan yang sangat besar pengaruhnya terhadap kelestarian tinggalan-tinggalan monumental tersebut. Oleh karenanya perlu suatu penanganan secara khusus untuk mengatur serta mengelola suatu sumberdaya budaya dengan berbagai konflik kepentingan yang ada, agar sumberdaya budaya tesebut tidak terancam kelestariannya dan berbagai konfliks kepentingan yang ada dapat ditekan semaksimal mungkin sehingga tidak terdapat pihak-pihak yang merasa dirugikan, tetapi justru merasa diuntungkan. Adapun langkah langkah yang dilakukan antara lain dengan Pengembangan Sumberdaya Manusia dan Pemberdayaan Masyarakat.

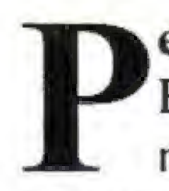

engembangan Suberdaya Manusia

Pengembangan Sumberdaya manusia dapat diartikan sebagai upaya mempersiapkan seseorang, baik sebagai individu maupun sebagai anggota masyarakat dengan segala kedudukannya. Artinya upaya tersebut tidak hanya terbatas 
pada upaya pembinaan kemampuan fisik, tetapi juga upaya pembinaan mental sebagai pendukung suatu kebudayaan. Sehingga pengembangan sumberdaya manusia harus dapat mempersiapkan kemampuan atau ketrampilan jasmaniah agar seseorang dapat memenuhi kebutuhan hidupnya. Disamping itu pengembangan sumberdaya manusia juga harus dapat mempersiapkan seseorang untuk dapat berperan dalam kehidupan sosial secara mantap. Oleh karena itu dalam praktek komunikasi atau interaksi sosial, secara efektif dapat terselenggara kalau terdapat pranata, aturan, hukum, undangundang dan lain sebagainya yang semuanya didasari oleh nilai-nilai, gagasan ataupun keyakinan yang mendominasi kehidupan masyarakat yang bersangkutan.

Masalah yang secara umum dihadapi oleh masyarakat kita adalah suatu kenyataan bahwa kita hidup dalam masyarakat yang majemuk dengan latar belakang aneka ragam budaya. Disamping itu berkenaan dengan pembangunan yang merupakan upaya peningkatan kesejahteraan yang dalam penyelenggaraannya dilakukan secara singkat. Banyak teknologi dan ilmu pengetahuan asing yang diadopsi untuk mempercepat suatu proses. Akibatnya, menuntut adaptasi (penyerapan) ke dalam sistem budaya yang ada, bahkan tidak mungkin akan menggeser nilai-nilai yang tidak sesuai . Masalah yang lain adalah adanya kontak dengan pihak asing yang dipermudah dengan kemajuan teknologi

Untuk mengatasi permasalahan demikian adalah sesuatu yang tidak gampang untuk dilakukan, karena diperlukan suatu sistem sosial yang mampu mengendalikan pergaulan antara sesama penduduk tanpa memandang asal kesukuan, etnis, maupun golongan. Disamping itu dalam upaya mengembangkan sistem sosial yang memadai diperlukan landasan yang diterima sebagai acuan bersama, yaitu kebudayaan seabagai sistem nilai, gagasan dan keyakinan.

Sementara itu dalam hal pengembangan sumberdaya budaya, seharusnya kita ketahui atau kita pelajari terlebih dahulu tentang nailai-nilai dan makna kultural yang terdapat di dalamnya. Sumberdaya budaya yang bersifat tangible, sebagai karya manusia dari masa lalu yang juga dikenal sebagai warisan budaya tersebut hendaknya dijunjung tinggi, karena di dalamnya terdapat nilai-nilai tinggi yang terlihat melalui nilai-nilai sosial dan individu yang membentuk jalinan tradisi dan adat istiadat yang kemudian menghasilkan produk benda-benda budaya oleh lingkungan masyarakat tertentu dan pada zaman tertentu pula.

Karya-karya budaya yang memiliki kepastian dalam bentuk fisik akan dapat berubah maknanya, bahkan sering menemukan makna baru yang jauh berbeda dengan arti penciptaan semula. Konsep kebudayaan tradisional dan moderen pada dasarnya menunjukkan dinamika perkembangan budaya masyarakat yang sama di dalam menempuh perubahan-perubahan zaman. Oleh karenanya kebudayaan dapat disebut sebagai perwujudan dari kemampuan keseluruhan hidup masyarakat dalam 
menghadapi tantangan lingkungan secara spasial dan temporal dalam upaya mewujudkan pengalaman kehidupannya.

\section{$\mathbf{P}$} emberdayaan Masyarakat

Istilah pemberdayaan seringkali digunakan dalam konteks kemampuan meningkatkan keadaan ekonomi (pemenuhan kebutuhan paraktis) seseorang . Pengertian ini mencerminkan bahwa proses pemberdayaan merupakan upaya perbaikan atau peningkatan ekonomi, sosial-budaya, politik dan psikologis, baik secara individu maupun secara kolektif yang berbeda menurut kelompok etnik dan kelas sosial.

Strategi pendekatan dapat dilakukan secara individual maupun kolektif dengan saling memberdayakan antara satu dengan yang lain. Upaya ini dapat dilakukan dengan menumbuhkan kesadaran, mendorong dan membantu potensi yang ada pada suatu kelompok masyarakat, sehingga mereka menjadi seseorang yang mandiri tetapi tetap berkepribadian dalam arti masyarakat dapat melakukan pengembangan diri dan menentukan nasib sendiri dengan menggunakan cara-cara yang demokratis atas dasar kebersamaan, kesetaraan dan tenggang rasa (Prijono, $1996: 200-201$ ).

Kelestarian situs Candi Morangan, benar-benar perlu dijaga kelestariannya. Karena situs tersebut merupakan salah satu aset budaya yang dimiliki oleh daerah terutama wilayah Kabupaten Sleman, Propinsi Daearah Istimewa Yogyakarta. Kekhawatiran yang muncul pada bangunan candi Bata tersebut adalah semakin lama semakin terancam keselamatannya yang dapat disebabkan oleh beberapa faktor;

1. Kerusakan yang disebabkan oleh faktor alam, misalnya gempa bumi, Banjir. Dan gunung meletus.

2. Kerusakan oleh faktor kimia, seperti adanya pengruh oksidasi.

3. Kerusakan yang disebabkan oleh faktor biologik, yaitu disebabkan oleh perlakukan benda-benda hidup, seperti tanaman, binatang dan manusia.

Dari hasil pengamatan terhadap situs candi Morangan ini, terdapat dua faktor yang kemungkinan menjadikan rusaknya bangunan candi tersebut, yaitu faktor mekanik, sebagai akibat dari letusan gunung, dan faktor biologik yang bersumber pada perlakukan manusia. Faktor kerusakan yang bersumber dari perlakukan manusia inilah merupakan salah satu faktor yang sangat sulit untuk diatasi. Hat ini sangat sulit untuk di atasi karena menyangkut kepentingan-kepentingan yang bertentangan antara pengelola situs dengan pemilik tanah, karena sebagai pemilik tanah ia merasa berhak untuk menggarap tanahnya untuk pertanian, pembuatan bata dan kepentingankepentingan lain yang berhubungan dengan ekonomi. 
Dalam upaya mengantisipasi hal tersebut, yaitu agar keberadaan bangunan candi tidak semakin rusak, sebenarnya secara yuridis sudah ada undang-undang no. 5 tahun 1992 , tentang Cagar Budaya. Akan tetapi dengan adanya beberapa kepentingan, terutama kepentingan ekonomi untuk memenuhi kebutuhan hidupnya. Maka agar bangunan candi bata tersebut tidak semakin terancam kelestariannya, perlu upaya-upaya yang lain;

Adapun langkah yang paling mendesak untuk dilakukan adalah menekan atau mengurangi tingkat kerusakan sebagai akibat dari kegiatan masyarakat. Beberapa hal yang penting untuk dilakukan dalam rangka pelestarian dan penyelamatan adalah;

- Melakukan kontrol terhadap bangunan candi melalui petugas yang ditunjuk oleh instansi terkait (BP-3).

- Menjalin kerjasama yang erat antara Pemerintah Daerah, BP-3 dan masyarakat.

Terkait dengan keberadaan situs Candi Morangan, masyarakat di sekitar situs (Candi Morangan), oleh pemerintah melalui instansi yang berwenang menangani situs tersebut dapat menerapkan strategi pendekatan paling tidak dengan menumbuhkan kesadaran kepada masyarkat. Hal ini dimaksudkan, mengingat pentingnya suatu sumberdaya budaya (bangunan candi Morangan) memiliki nilai yang cukup penting bagi sejarah budaya bangsa. Sehingga dengan tumbuhnya kesadaran masyarakat, maka upaya pelestarian semakin mudah untuk dilakukan, karena dengan tumbuhnya kesadaran itulah rasa ikut memilkiki akan meklekat pada masyarakat.

Dengan demikian, melalui pemberdayaan masyarakat sehingga munculnya kesadaran masyarakat akan pentingnya candi Morangan sebagai sumberdaya budaya, maka besar kemungkinan berbagai konflik kepentingan yang ada dapat ditekan semaksimal mungkin, sehingga upaya pelestarian terhadap bangunan candi Moramngan tersebut dapat berjalan dengan lancar.

\section{Tesimpulan \\ Mengingat jumlah sumberdaya budaya yang terbatas (finite), tak terbaharui 1 (non renewable), tak dapat dipindahkan (non movable), serta mudah rapuh, maka dalam pemanfaatan sumberdaya budaya haruslah berorientasi pada pelestarian. Oleh karena itu dalam upaya pemanfaatan terhadap sumberdaya budaya hendaknya dimanfaatkan dengan hati-hati. Kemudian dalam hal pengembangan terhadap aset budaya harus pula melihat nilai dari berbagai kepentingan, sehingga berbagai konflik kepentingan yang ada dapat ditekan sesejauh mungkin agar tidak ada upaya untuk saling mengalahkan, tetapi saling menguntungkan.}

Sebagai sumberdaya budaya yang merupakan produk masa lampau memiliki potensi pendidikan bagi generasi bangsa serta dapat menyadarkan bangsa akan sejarah di 
masa lampau. Dalam era seperti sekarang ini, kita harus memiliki ketahanan budaya agar tidak mudah terombang ambing oleh persentuhan budaya asing yang tidak sesuai dengan budaya bangsa kita. Jika suatu ketahanan budaya telah kita miliki, maka perusakan budaya tidak akan terjadi, meskipun kontak budaya bangsa kita dengan budaya asing tidak dapat dihindari. Dalam hal kepentingan ideologi, upaya pengembangan tehadap sumberdaya budaya akan menambah rasa kebanggaan bangsa dan dapat memperkuat jati diri bangsa, sehingga akan menambah dan memperkuat rasa kebangsaanya. Sementara itu dalain hal kepentingan ekonomi, suatu sumberdaya budaya dapat bermanfaat untuk kemajuan ekonomi melalui sektor pariwisata, yang dalam hal ini terdapat tiga sektor yang berkepentingan, berkaitan dengan keberadaan aset budaya, yaitu pemerintah, akademisi dan masyarakat publik yang dalam upaya pemanfaatan serta pengembangannya harus seimbang, dan harus memperhatikan kepentingan masyarakat luas serta berorientasi ke masa depan.

Disamping itu, upaya pelestarian terhadap peninggalan sejarah dan purbakala adalah suatu upaya untuk menjaga kelestarian suatu obyek dengan segala potensi yang ada sehingga dapat bermanfaat untuk kesejahteraan hidup manusia. Oleh karena itu upaya pelestarian harus diawali dengan menumbuhkan apresiasi masyarakat tentang pentingnya warisan budaya yang dapat dimanfaatkan untuk peningkatan jati diri dan peningkatan kesejahteraan hidup masyarakat. Dengan demikian, upaya pelestarian terhadap suatu sumberdaya budaya dilaksanakan dengan mempertimbangkan asas manfaat, sedangkan dalam pemanfaatan benda cagar budaya harus selalu berwawasan pelestarian.

DAFTAR PUSTAKA

Acharya, Prasanna Kumar. 1993. Archietecture of Manasara, London: Oxford University Press.

Boechari, 1978. Bahan Kajian Arkeologi untuk Pengajaran Sejarah, Majalah Arkeologi Th. II, No. 1, September.

Kempers, A.J. Bernet. 1959. Ancient Indonesian Art, Amsterdam: Harvard University Press.

Kramrisch, Stella. 1946. The Hindu Temple, Calcutta: University of Calcuta. 
Krom, N.J., 1923. Inleiding tot de Hindoe Javaansche Kunst, 2de, 's-Gravenhage: M. Nijhoff.

Mundardjito. 1993. Pertimbangan Ekologi dalam Penempatan Situs Masa HinduBuda di Daerah Yogyakarta: Kajian Arkeologi Ruang Skala Makro, Disertasi, Universitas Indonesia, Jakarta.

Prijono, Onny, S, dan Pranarka, A.M.W. 1996. Pemberdayaan, Konsep,Kebijakan dan Implementasi, CSIS (Center For Strategic and International Studies), Jakarta.

Stutterheim, W.F., 1937. He Zinrijke Waterwerk van Djalatoenda, TBG LXVII, hlm. 173-216,

Tjahjono, Baskoro, D. 2003. Laporan Penelitian Arkrologi, (LPA) Balai arkrologi Yogyakarta. 